\title{
Analysis of Genetic Mutations and the Clinical Manifestations of Neurofibromatosis Type 2 in Korea: A Single Institutional Experience
}

\author{
Hyun Tag Kang ${ }^{1}$ iD, Jae Yong Lee ${ }^{2}$, Yun Ji Lee ${ }^{1}$, Se A Lee ${ }^{1}$, Byung Ryul Jeon ${ }^{3}$, and Jong Dae Lee ${ }^{1}$ \\ ${ }^{1}$ Departments of Otorhinolaryngology-Head and Neck Surgery, ${ }^{3}$ Pathology, Soonchunhyang University College of Medicine, \\ Bucheon Hospital, Bucheon; and \\ ${ }^{2}$ Department of Otorhinolaryngology-Head and Neck Surgery, Soonchunhyang University College of Medicine, Seoul Hospital, \\ Seoul, Korea
}

국내 제 2 형 신경섬유종증 환자의 유전자 돌연변이와 임상증상 분석

강현택 ${ }^{1} \cdot$ 이재용 ${ }^{2} \cdot$ 이윤지 ${ }^{1} \cdot$ 이세아 ${ }^{1} \cdot$ 전병열 $^{3} \cdot$ 이종대 $^{1}$

순천향대학교 의과대학 부천병원 이비인후-두경부외과학교실, ${ }^{1}$ 병리학교실, ${ }^{3}$

순천향대학교 의과대학 서울병원 이비인후-두경부외과학교실

Received September 17, 2020

Revised November 19, 2020

Accepted November 19, 2020

Address for correspondence

Jong Dae Lee, MD, PhD

Department of Otorhinolaryngology,

Soonchunhyang University

College of Medicine,

170 Jomaru-ro, Wonmi-gu,

Bucheon 14584, Korea

Tel $+82-32-621-5015$

Fax $+82-32-621-5016$

E-mail ljdent@schmc.ac.kr
Background and Objectives Neurofibromatosis type 2 (NF2) is a rare autosomal dominant disorder characterized as bilateral vestibular schwannoma (VS), various brain and spinal tumors. This study is aimed to investigate the relationship between the genotypes and phenotypes of NF2 found in the Korean population.

Subjects and Method We retrospectively reviewed 11 patients who were diagnosed with NF2 and observed them for more than a year. NF2 gene mutations were detected using Sanger sequencing and multiplex ligation-dependent probe amplification (MLPA). The mutations were classified into tissue mosaicism, classic, and severe genotypes according to the UK NF2 genetic severity score. Tumor load was assessed by reviewing MR images and audiological findings were analyzed.

Results We identified 7 cases (63.6\%) of mutations from 11 patients who were diagnosed with NF2. While three patients showed classic and four showed severe genotypes, four patients were presumed as tissue mosaicism. The patients with severe genotypes didn't show more severe clinical manifestations in terms of tumor load and hearing. Four patients with tissue mosaicism were detected in the older age group than those with mutation. Of the five patients who had serviceable bilateral hearing at the initial diagnosis, all maintained their serviceable hearing during the follow-up.

Conclusion Our results, which showed that the clinical manifestations of NF2 found in the Korean population have no correlation with the genotype findings, are not in agreement with previous studies. However, further studies with larger sample sizes are needed to give more appropriate counsel. Korean J Otorhinolaryngol-Head Neck Surg 2021;64(10):703-10

Keywords Genetic; Mutation; Neurofibromatosis type 2.

This is an Open Access article distributed under the terms of the Creative Commons Attribution Non-Commercial License (https://creativecommons.org/licenses/by-nc/4.0) which permits unrestricted non-commercial use, distribution, and reproduction in any medium, provided the original work is properly cited. 


\section{서 론}

제2형 신경섬유종증(neurofibromatosis type 2, NF2)은 22번 염색체에 있는 NF2 종양 억제 유전자의 변이로 인해 말 초신경 또는 중추신경 조직에서 다발성 종양이 발생하는 매 우 드문 질환이다. 상염색체 우성으로 유전되는 제2형 신경섬 유종증은 약 60000 명당 1명 정도의 유병률을 보이며, ${ }^{1)}$ 이 질 환에 이환된 환자들은 신경계, 눈, 피부 병변이 발생하게 된 다. 양측성 전정신경초종(vestibular schwannoma)은 제2형 신경섬유종증 환자에서 가장 흔하게 보이는 임상 양상이나 다른 뇌신경, 척수신경, 말초신경에서도 신경초종(schwannoma)이 발생할 수 있다. 양측성 전정신경초종이 있거나, 일 측성 전정신경초종인 경우에도 수막종(meningioma), 신경교 종(glioma), 신경섬유종(neurofibroma), 백내장(cataract)이 있는 경우 제2형 신경섬유종증으로 진단할 수 있다. 자세한 진단 기준은 Table 1 에 기술하였다.,3)

영국의 유전적 중증도 점수(Genetic Severity Score) 지표 는 제2형 신경섬유종증 환자들의 유전자형에 따라 표현형을 분류한 것이다(Table 2). 돌연변이에 따라서 조직 섞임증(tissue mosaicism), 전형적(classic), 중증(severe)의 세 가지 분 류로 나누며, 제2형 신경섬유종증 환자들의 예후를 추측하 여 환자를 상담하거나 수술적 처치나 정위적 방사선 치료를 결정할 때 참고지표로 사용한다.

미국과 유럽에서는 제2형 신경섬유종증의 유전형과 표현형 의 연관성이 잘 규명되어 있다. 일반적으로 절단형 돌연변이 (truncating mutation)를 가질수록 심한 임상 증상이 나타나며,

Table 1. NF2 clinical diagnostic criteria

\begin{tabular}{|c|c|}
\hline Primary finding & Additional features needed for diagnosis \\
\hline Bilateral VS & No needed \\
\hline \multirow[t]{3}{*}{ First degree relative with NF2 } & Unilateral VS \\
\hline & OR \\
\hline & Any 2 other NF2-associated lesions: meningioma, schwannoma, glioma, neurofibroma, cataract \\
\hline Unilateral VS & Any 2 other NF2-asoociated lesions: meningioma, schwannoma, glioma, neurofibroma, cataract \\
\hline \multirow[t]{3}{*}{ Multiple meningiomas } & Unilateral VS \\
\hline & OR \\
\hline & Any 2 other NF2-associated lesions: neurofibroma, cataract \\
\hline
\end{tabular}

Table 2. UK NF2 Genetic Severity Score

\begin{tabular}{|c|c|c|c|}
\hline Genetic severity & Subcategory & Clinical characteristics & Definition \\
\hline \multirow[t]{2}{*}{1 Tissue mosaic } & $1 \mathrm{~A}$ & Presumed tissue mosaicism & $\begin{array}{l}\text { Meets clinical criteria for sporadic NF2 but not confirmed } \\
\text { molecularly with identical NF2 mutations detected in two } \\
\text { separate tissue samples }\end{array}$ \\
\hline & 1B & Confirmed tissue mosaicism & $\begin{array}{l}\text { Mosaic NF2 confirmed molecularly with identical NF2 mutations } \\
\text { detected in two or more separate tissue samples }\end{array}$ \\
\hline \multirow[t]{2}{*}{2 Classic } & $2 \mathrm{~A}$ & Mild NF2 & $\begin{array}{l}\text { Full or mosaic NF2 mutation identified in blood excluding those } \\
\text { found in group } 2 \text { B or } 3 \text { : } \\
\text { Missense mutations; } \\
\text { In-frame deletions and duplications; } \\
\text { Deletions involving the promotor region or exon 1; } \\
\text { Splice site mutations in exons } 8-15 \text {; } \\
\text { Truncating mutations of exon 1; } \\
\text { Mosacisim in blood for mutations other than truncating mutations } \\
\text { in exons } 2-13\end{array}$ \\
\hline & $2 B$ & Moderate NF2 & $\begin{array}{l}\text { Full or mosaic NF } 2 \text { mutation identified in blood including: } \\
\text { Splicing mutation involving exons } 1-7 \text {; } \\
\text { Large deletion not including the promotor or exon 1; } \\
\text { Truncating mutations in exons } 14-15 \text {; } \\
\text { Mosaic in blood for a truncating mutation in exons } 2-13\end{array}$ \\
\hline 3 Severe & 3 & Severe NF2 & Full NF2 truncating mutation exons $2-13$ \\
\hline
\end{tabular}

NF2: neurofibromatosis type 2. Adapted from Halliday, et al. J Med Genet 2017;54(10):657-64. ${ }^{4}$ 
절단부 돌연변이(splice site mutation), 체세포 섞임증(somatic mosaicism), 과오 돌연변이(missense mutation)인 경우 상대 적으로 늦은 나이에 증상이 나타나는 편이라 알려져 있다. ${ }^{5-9)}$

저자들이 조사한 바에 따르면, 아시아에서는 제2형 신경섬 유종증의 유전형이 새롭게 보고된 것 외에는 유전형과 표현 형의 연관성에 대해 연구된 자료는 없는 상태이다. 이에 본 연구에서 유전적 중증도 점수 지표를 이용하여 한국에서의 제 2 형 신경섬유종증 환자들의 유전형과 표현형 사이의 연관 성을 알아보고자 하였다.

\section{대상 및 방법}

\section{대 상}

2010년 1월 2020년 5월까지 순천향대학교 부천병원 이비 인후과에 내원한 환자 중 제2형 신경섬유종증으로 진단받은 환자 27 명의 의무기록과 유전자 검사 결과를 후향적으로 분 석하였다. 이들 중 영상의학적 검사를 통해 양측성 전정신경 초종이 확인된 환자 중 1년 이상 추적 관찰한 환자를 포함하 였고, 일측성 전정신경초종을 갖고 있거나 유전자 검사를 시 행하지 않은 환자들은 제외하였다. 각 환자의 외래 내원 당시 주 증상, 처음 진단된 날짜, 청력검사, 영상의학적 검사 결과, 안과 진료기록지 등의 의무기록을 통해 조사하였다. 본 연구 는 본원 연구윤리 심의 위원회(Institutional Review Board, IRB)의 승인을 받아 시행하였다(IRB No. 2020-08-018).

\section{유전자 검사}

각 환자들의 말초 혈액을 채취하여 유전자 돌연변이 검사 를 시행 후 유전적 중증도 점수에 따라 분류하였다. 돌연변이 검사는 직접 DNA 염기서열검사(direct DNA sequencing)와 다중결찰의존 프로브 증폭(multiplex ligation-dependent probe amplification, MLPA)을 사용하였다.

직접 $\mathrm{DNA}$ 염기서열검사는 환자들의 말초혈액으로부터 얻 은 백혈구의 DNA를 이용하였다. Wizard ${ }^{\circledR}$ Genomic DNA Purification Kit(Promega, Madison, WI, USA)를 이용하여 추출된 DNA는 제2형 신경섬유종증 유전자의 전체 코딩 영 역(exon 1-16)과 엑손-인트론(exon-intron) 경계를 적절한 시 동체 세트(primer set)를 이용하여 중합 효소 연쇄반응(polymerase chain reaction)으로 증폭시켰다. 각 중합 효소 연쇄 반응 산물들은 BigDye Terminator Cycle Sequencing Ready Reaction Kit(Applied Biosystems, Rotkreuz, Switzerland) 로 순환 순서 결정(cycle sequencing) 후 ABI Prism $3130 \mathrm{Ge}^{-}$ netic Analyzer(Applied Biosystems)으로 전기영동을 하였다. 발견된 유전자 변이는 DNA sequence assembly software
Sequencher 4.10.1(Gene Codes Corporation, Ann Arbor, MI, USA)을 이용하여 분석하였으며, GenBank의 제2형 신 경섬유종증 시퀀스(GenBank ID NM_000268.3)를 참조서 열로 사용하였다.

돌연변이 서열이 발견되지 않거나, 중합 효소 연쇄반응이 실패한 경우, 큰 돌연변이(large mutation)를 확인하기 위해, SALSA P044-NF2 Kit(MRC-Holland, Amsterdam, Netherlands)을 이용하여 다중결찰의존 프로브 증폭(MLPA)을 시행하였다. ABI 9700 Thermal Cycler(Model 9700; Applied Biosystems, Foster City, CA, USA)를 이용하여 프로브 혼 합물과 교잡하여 결합시킨 후 중합 효소 연쇄반응 증폭을 하 였으며, 중합 효소 연쇄반응 증폭 산물은 ABI Prism 3130x1 Genetic Analyzer(Applied biosystems)를 이용하여 전기영 동을 시행하고 GeneMarker 1.9 software(SoftGenetics, LLC, State College, PA, USA)를 통해 분석하였다.

\section{청력검사}

모든 환자들은 내원 당시 순음청력검사와 어음명료도검사 를 시행하였으며, 순음청력검사는 $0.5,1,2,3 \mathrm{kHz}$ 주파수의 청력역치의 평균으로 계산하였고, 어음명료도검사는 단음절 단어 목록을 환자에게 읽게 한 뒤 정확히 발음한 경우를 퍼 센트로 표시하였다. 각 환자들의 순음역치평균과 어음명료도 수치는 American Academy of Otolaryngology-Head and Neck Surgery(AAO-HNS) 분류법을 이용해 A, B, C, D군으 로 분류하였다(Fig. 1). ${ }^{10}$ 사회적응청력은 $\mathrm{AAO}-\mathrm{HNS}$ 분류법

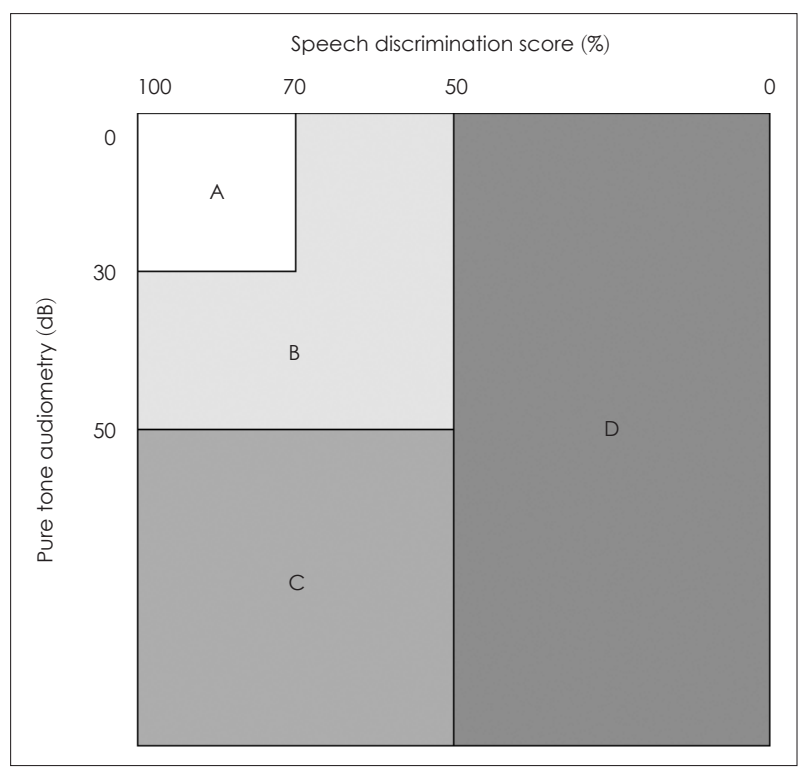

Fig. 1. Patient's hearing at diagnosis according to American Academy of Otolaryngology-Head and Neck Surgery classification. ${ }^{10)}$ Classification $A$ and $B$ accounts for serviceable hearing. Adapted from Committee on Hearing and Equilibrium; Monsell, et al. Otolaryngol Head Neck Surg 1995;113(3):179-80. ${ }^{10}$ 


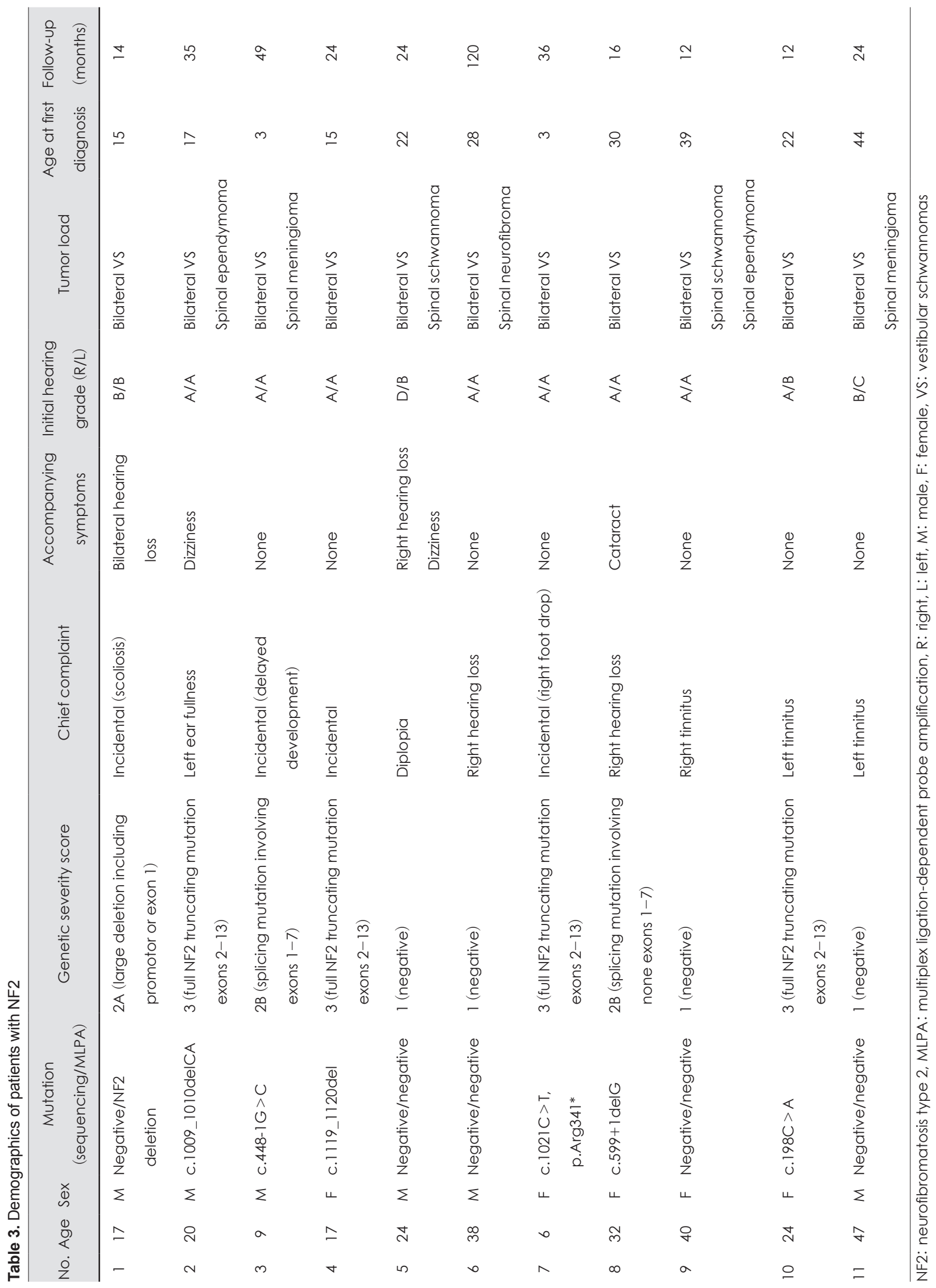


에서 순음역치평균이 $50 \mathrm{~dB} \mathrm{HL}$ 미만이고, 어음명료도가 $50 \%$ 를 초과하는 $\mathrm{A}$ 군과 $\mathrm{B}$ 군에 해당하는 구간의 청력으로 정의하 였다.

\section{영상검사 및 안과 진료 기록부 확인}

환자들은 첫 내원 당시 조영증강 측두골 자기공명영상과 조영증강 척추 자기공명영상을 촬영하여, 전정신경초종이나 수막종, 척추종양 등이 있는지 평가하였다. 또한 환자들은 최 초 내원 당시부터 주기적인 안과검진을 시행하여 백내장, 시 신경수막종(optic nerve meningioma), 망막전막(epiretinal membrane), 시신경교종(optic nerve glioma), 망막과오종 (retinal harmatoma) 등의 여부를 확인하였다.

\section{결 과}

27명의 제2형 신경섬유종증 환자들 중 본 연구에 포함된 환자는 총 11 명으로, 2 명은 제 2 형 신경섬유종증 가족력이 있 었고(사례 8번, 10 번), 그 외 9명은 산발적 제2형 신경섬유종 증이었다. 환자 연령은 6 47세로 다양하게 분포하였고 평균 현재 연령은 24.9세였으며, 첫 진단 시 평균 연령은 21.6세였 다. 남녀 비율은 6:5로 비슷하였고, 평균 추적 관찰 기간은 약 33 개월이었다. 양측 청력역치를 비교하여 좋은 귀(better ear) 를 대상으로 했을 때, $\mathrm{AAO}-\mathrm{HNS}$ 기준 $\mathrm{A}$ 군은 8명, $\mathrm{B}$ 군은 3명, $\mathrm{C}$ 군과 $\mathrm{D}$ 군은 각각 0 명이었다.

유전자 검사에서는 11 명 중 7 명의 혈액에서 돌연변이가 확 인되었다. 엑손 2-13에 절단형 돌연변이가 있는 환자 4명, 엑 손 1-7에 절단부 돌연변이가 있는 환자 2명, 그리고 프로모터 (promotor)나 엑손 1에 결손 돌연변이가 있는 환자가 1명이었 다. 11 명 중 2 명을 제외하고 9 명의 양측 청력이 사회적응청력 에 해당되었다. 또한, 11 명 중 6 명에게서 양측성 전정신경초종 외에 척추종양이 존재하였다(Table 3).

유전적 중증도 점수에 따라 환자를 나누었을 때(Table 4), 그룹 1 에는 4 명의 환자가 포함되었고 환자들의 진단 당시의 평균 연령은 33.3 세였다. 이들 중 2 명이 양측 귀 모두 사회적 응청력을 가지고 있었고, 나머지 2명은 일측에서만 사회적응 청력을 보였다. 이들 중 한 명이 추적 관찰 기간 동안 $\mathrm{AAO}-$ $\mathrm{HNS}$ 기준으로 양측 귀 모두 $\mathrm{D}$ 군으로 청력이 저하되었다 (Fig. 2).

그룹 $2 \mathrm{~A}$ 에 해당하는 환자는 1 명이었다. 이 환자의 첫 진단 시의 연령은 15.0 세였으며, 청력은 $\mathrm{AAO}-\mathrm{HNS} \mathrm{B}$ 군에 해당되 었다.

그룹 $2 \mathrm{~B}$ 에는 2 명이 포함되었고 진단 당시의 연령은 각각 3 세, 30 세였다. 2 명의 모두 사회적응청력에 해당되었다.
Table 4. Clinical manifestations according to genetic severity grade

\begin{tabular}{lcccc}
\hline \multicolumn{1}{c}{ Genetic severity } & $\begin{array}{c}1 \\
\text { Tissue } \\
\text { mosaic }\end{array}$ & $\begin{array}{c}2 \mathrm{~A} \\
\text { Mild }\end{array}$ & $\begin{array}{c}2 \mathrm{~B} \\
\text { Moderate }\end{array}$ & $\begin{array}{c}3 \\
\text { Severe }\end{array}$ \\
\hline $\begin{array}{l}\text { Number of patients } \\
\text { Sex }\end{array}$ & 4 & 1 & 2 & 4 \\
$\quad 3$ & 1 & 1 & 1 \\
Male & 1 & 0 & 1 & 3 \\
Female & 33.3 & 15.0 & 16.5 & 14.3 \\
Hearing grade (better ear) & & & & \\
A & 2 & 0 & 2 & 4 \\
B & 2 & 1 & 0 & 0 \\
C & 0 & 0 & 0 & 0 \\
D & 0 & 0 & 0 & 0 \\
Ocular symptoms & 2 & 0 & 0 & 0 \\
Tumor load & & & & \\
Bilateral vestibular & 4 & 1 & 2 & 4 \\
$\quad$ schwannomas & & & & \\
Spinal meningioma & 1 & 0 & 1 & 0 \\
Spinal schwannoma & 2 & 0 & 0 & 0 \\
Spinal neurofibroma & 1 & 0 & 0 & 0 \\
Spinal ependymoma & 1 & 0 & 0 & 1 \\
\hline
\end{tabular}

그룹 3에는 4명의 환자가 포함되었다. 환자들의 첫 진단 시 의 평균연령은 14.3 세였으며, 청력은 4명 모두 사회적응청력 에 해당되었다(Fig. 3).

그룹 1 에서만 시력저하와 백내장 등의 안과적 증상이 동반 된 환자가 포함되었다. 영상의학적 검사에서 그룹 1 에 포함된 4 명 모두 척추종양이 동반되었으며, 그룹 $2 \mathrm{~B}$ 와 그룹 3 에서는 각각 한 명씩만 발견되었다.

첫 청력검사에서 17 세 이상이며, 양측 귀 모두 사회적응청 력에 해당된 5 명은 추적 관찰 기간 동안 사회적응청력을 유지 했다. 진단 시 한쪽 귀라도 사회적응청력에 해당하지 않는 환 자는 2 명이 있었고 모두 그룹 1 에 해당하였는데, 이들은 모두 추적 관찰 기간 동안 청력저하 소견을 보였다.

\section{고 찰}

제2형 신경섬유종증은 22번 염색체의 장완에 위치한 NF2 유전자의 돌연변이로 인해 발생한다. NF2 유전자는 멀린 (merlin)이라 불리는 종양억제 단백질을 구성하는데, 신경계 내의 슈반세포에서 생성되는 멀린은 세포가 빠른 속도로 성 장하거나 분할하지 못하게 조절하는 역할을 한다. NF2 유전 자가 변형되면 멀린이 정상적인 기능을 수행하지 못해 세포가 빠르게 성장하고 분열하여 양성종양을 발생시킨다. 제2형 신 경섬유종증 환자의 약 $95 \%$ 에서 양측성 전정신경초종이 발생 

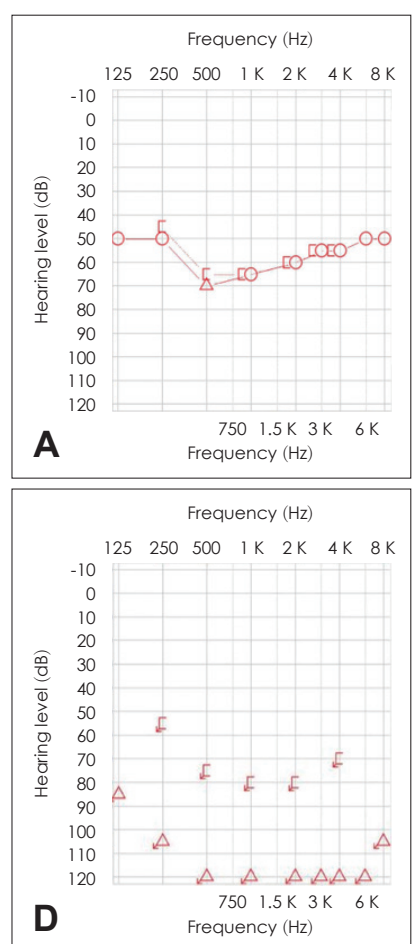

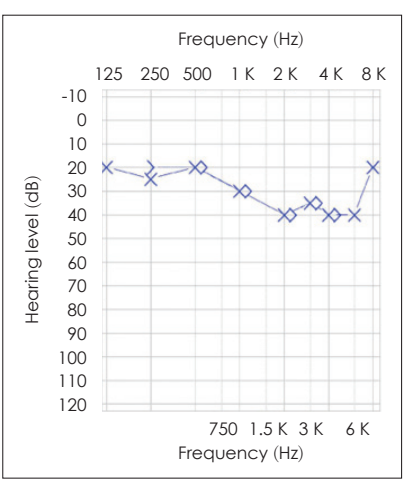

Frequency $(\mathrm{Hz})$

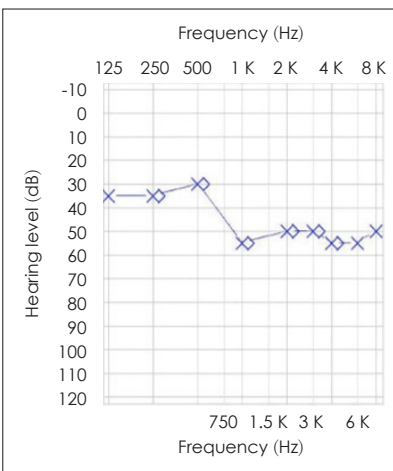

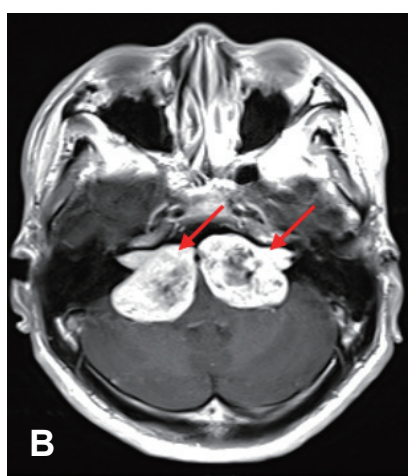
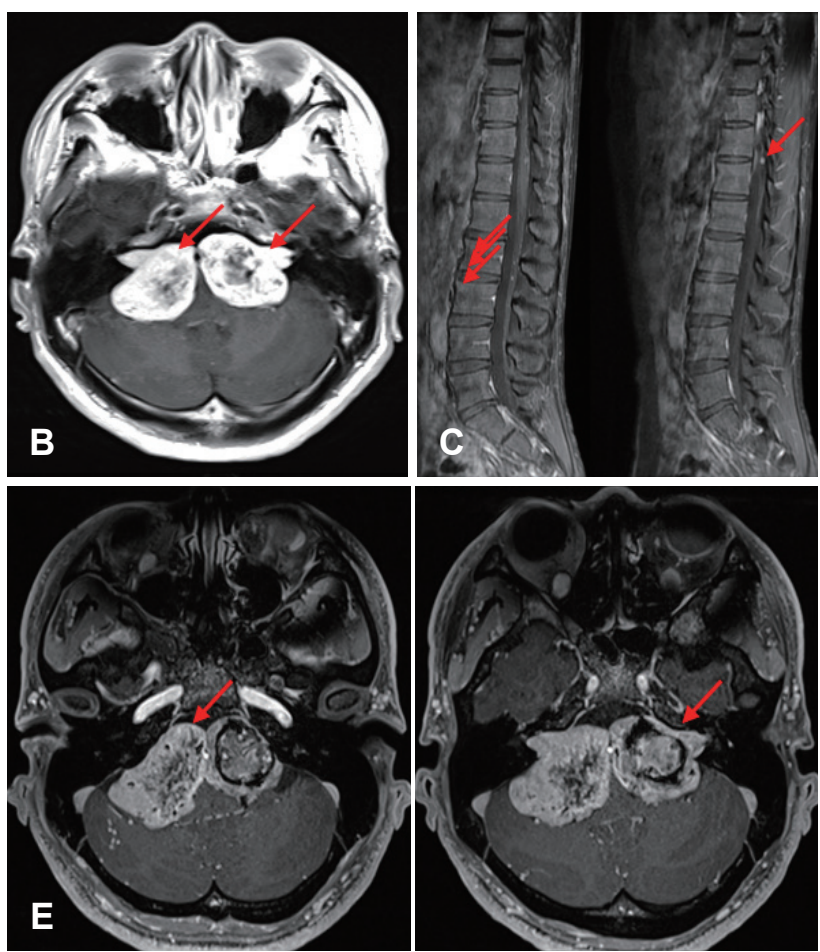

Fig. 2. 24-year-old male with chief complaint of diplopia. Initial pure tone audiometry shows group D in right ear, and group $B$ in left ear according to American Academy of Otolaryngology-Head and Neck Surgery classification (A). Gadolinum-enhanced T1-weighted MRI shows huge bilateral involving internal acoustic canal schwannomas involving cerebellopontine angle (right $3.84 \times 2.50 \mathrm{~cm}$, left $3.95 \times 2.65$ $\mathrm{cm}$ ) (arrows) (B). Cervical-thoracic-lumbar spine MRI shows multiple intradural extramedullary tumor. The patient's mutation analysis was negative indicating mild type neurofibromatosis type 2 (arrows) (C). After 1 year follow-up; pure tone audiometry showed worsened hearing level, right ear nearly deaf (D). In Gadolinum-enhanced T1-weighted MRI, the right schwannoma showed a $22 \%$ increase in size and the left schwannoma showed $4 \%$ increase in size (arrows) (E).

한다고 알려져 있으며, 난청, 이명, 어지럼증을 주로 호소한다. 본 연구에 포함된 환자들에서도 절반 이상에서 난청, 이명 등 의 귀 증상들을 주 증상으로 호소하였다.

제2형 신경 섬유종증은 치료 방침을 결정하기 매우 어려운 질병이다. 유전자형-표현형의 상관관계에 대한 연구들을 기 반으로 환자의 유전형에 근거한 예후 예측은 도움이 될 수 있다. 영국의 유전적 중증도 점수에 대해 진행된 선행 연구에 따르면 유전적 중증도와 첫 진단 시의 나이와 현재 나이는 음 의 상관관계를 가지며, 첫 진단 시 평균 나이는 그룹 1 의 경우 47.0세, 그룹 3의 경우 15.9 세로 알려져 있다. 또한 유전적 중 증도가 높은 그룹일수록 척추종양의 발견 빈도가 높았으며, 안과적 질환과 청력저하 또한 선형 경향성을 보인다고 보고 되었다. ${ }^{4}$

본 연구에서는 그룹 1 의 첫 진단 시 평균연령은 33.3 세, 그 룹 3의 첫 진단 시 평균연령은 14.3 세로 앞선 연구와 비슷한 경향성을 보였다. 그러나 청력의 경우 그룹 3에 포함된 4명 모 두 사회적응청력을 가지고 있었으며, 오히려 그룹 1에서 일측 의 사회적응청력에 포함되지 않는 청력을 가진 환자가 두 명 포함되었다. 안과적 질환을 가진 환자는 그룹 1 에서만 발견되 었으며, 그룹 1 의 환자들에게서 모두 척추종양이 확인되어,
1 명에게서만 척추종양만 확인된 그룹 3 과는 대비되는 모습을 보였다. 전체적으로 그룹 1 환자군이 그룹 3 환자군보다 심각 한 임상양상을 보여, 기존 보고된 연구의 결과와는 다른 경 향성을 띠었다.

유전적 중증도 점수와 청력의 관계를 연구한 다른 한 연구 에서는 유전적 중증도 점수에 따라, 조직 섞임증 그룹에서는 $\mathrm{AAO}-\mathrm{HNS} \mathrm{A}$ 군인 환자가 $64 \%$ 가량 되었으나, 중증 그룹에 서는 절반 이상의 환자가 사회적응청력을 잃어버렸고, $35 \%$ 만 이 AAO-HNS A군에 해당되었다. ${ }^{11)}$ 본 연구에서는 조직 섞임 증 그룹 중 AAO-HNS A군에 해당하는 환자는 4명 중 2명, 중증 그룹에서 $\mathrm{A}$ 군에 해당하는 환자는 4 명 중 4 명이었다. 이 는 기존 연구와 차이점을 보이는 결과이나 대상 환자 수가 적어 추가적인 연구가 필요할 것으로 보인다.

이전 연구에 따르면 제2형 신경섬유종증 환자들은 나이가 들어감에 따라 청력이 떨어지는 모습을 보이는데, 조직 섞임 증 그룹의 환자들 중 절반은 80세까지 사회적응청력을 유지 하나 경도와 중등도 그룹에서는 44 46세, 중증 그룹에서는 32세에 절반의 환자가 사회적응청력을 잃어버린다고 하였다.11)

본 연구에서 첫 진단 시 17세 이상이며 양측 귀 모두 $\mathrm{AAO}-$ $\mathrm{HNS} \mathrm{A군에} \mathrm{해당된} 5$ 명은 추적 관찰 기간 동안 정상청력을 

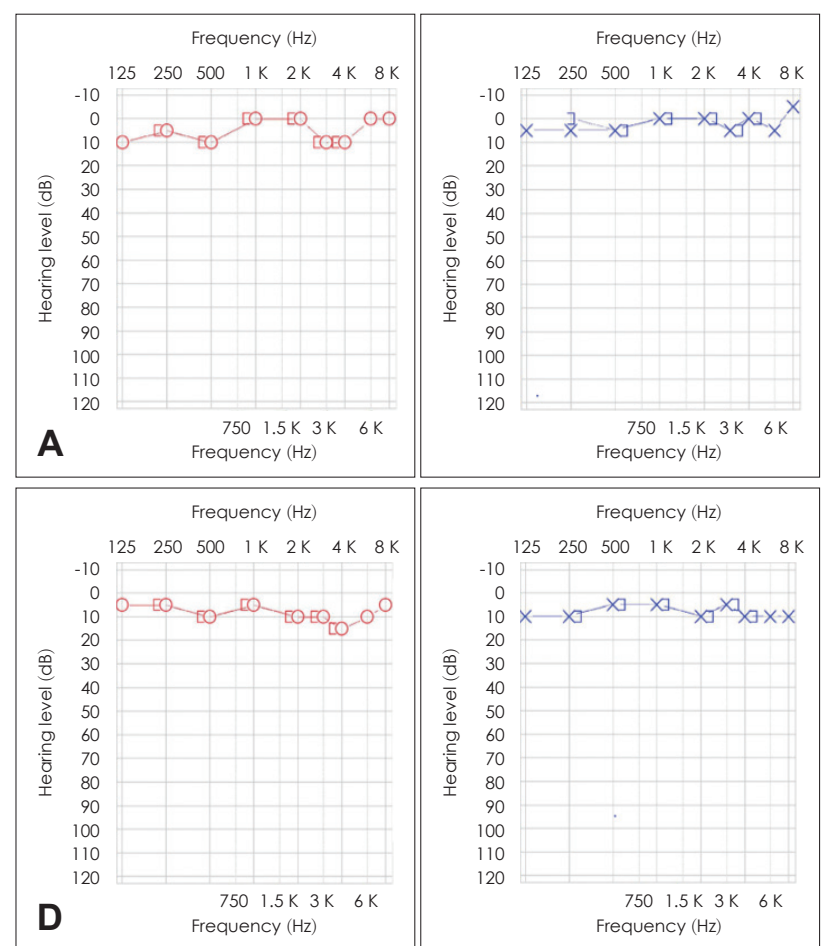

Frequency $(\mathrm{Hz})$

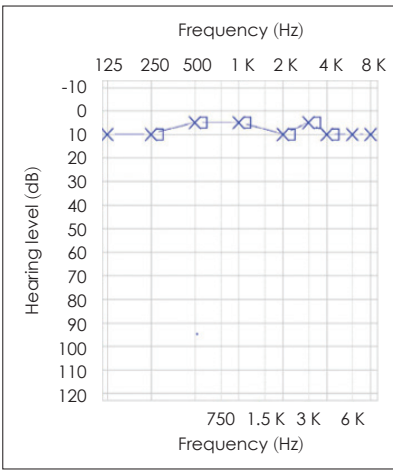

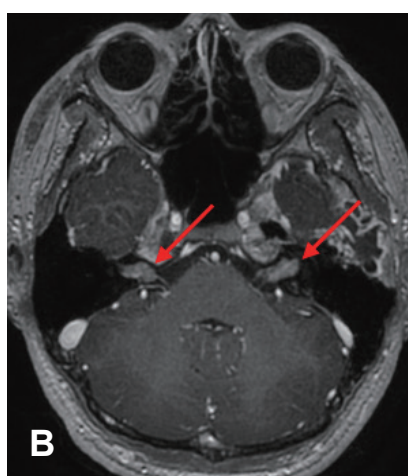

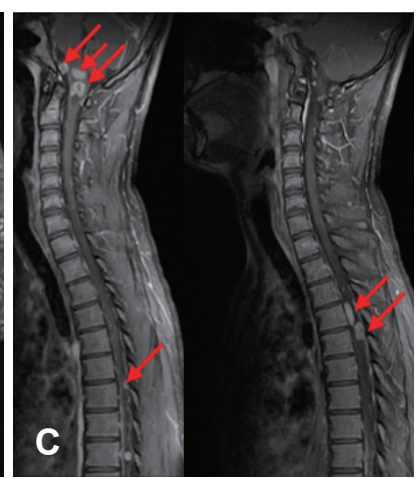

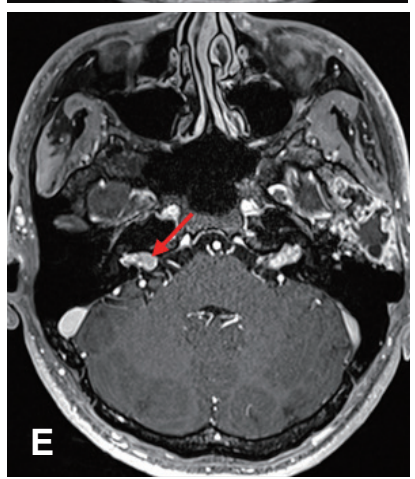

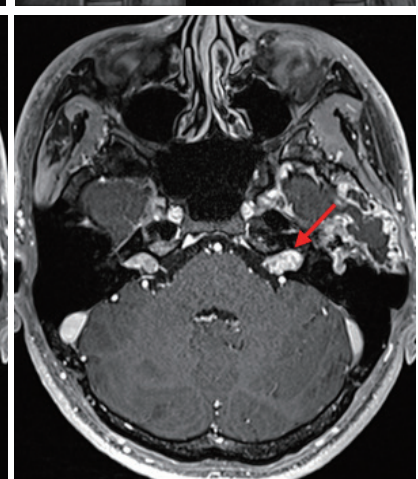

Fig. 3. 20-year-old man with chief complaint of tinnitus. Pure tone audiometry shows normal hearing level on initial visit (A). Gadolinumenhanced T1-weighted MRI demonstrating bilateral schwannomas involving internal acoustic canal (arrows) (B). Cervical-thoracic-lumbar spine MRI shows multiple intradural extramedullary spine tumor. The patient's mutation analysis revealed truncating mutation in exon 11 (c.1119_1120del) indicating severe type neurofibromatosis type 2 (arrows) (C). After 2 years follow-up; pure tone audiometry shows maintaine $\bar{d}$ normal hearing level (D). In gadolinum-enhanced T1-weighted MRI, bilateral schwannomas did not show significant size increase (arrows) (E).

유지하였으며 가장 긴 추적 관찰 기간은 35 개월이었다. 이전 연구결과와 다르게 연령에 따라 청력저하가 진행되는 모습을 보이지 않았으나, 환자들의 나이가 이전 연구의 각 군에 따른 사회적응청력을 잃어버리는 평균 연령대에 미치지 못하므로 보다 장기간의 추적 관찰이 필요할 것으로 보인다.

본 연구는 동양인에서 유전적 중증도 점수를 이용하여 제 2형 신경섬유종증의 유전자형과 표현형의 연관성에 대해 연 구한 첫 논문이라는 의미가 있다. 결과적으로 제2형 신경섬유 종증 환자들은 유전자형과 표현형이 기존에 알려진 연구들과 일치하지 않는 것으로 나타났다. 또한 첫 진단 시에 사회적응 청력을 가지고 있다면 유전자형과 상관없이 청력을 유지할 수 있는 것으로 생각된다.

본 연구의 제한점으로는 단일 기관 연구이고, 환자 수가 매 우 적었기 때문에, 한국 제2형 신경섬유종증 환자의 유전자 형과 표현형의 관계에 대한 결론을 도출하는 데 한계가 있었 다. 앞으로 다기관 연구 등을 통해 더 많은 환자 자료를 이용 하여 인종간의 차이나 후성적 요인들을 함께 분석하는 추가 연구가 필요할 것으로 보인다.

\section{Acknowledgments}

This study was supported by the Soonchunhyang University Research Fund.

\section{Author Contribution}

Conceptualization: Jong Dae Lee. Data curation: Hyun Tag Kang, Jae Yong Lee, Yun Ji Lee, Se A Lee, Byung Ryul Jeon. Formal analysis: Se A Lee, Jong Dae Lee. Investigation: Hyun Tag Kang. Methodology: Byung Ryul Jeon, Jong Dae Lee. Project administration: Jong Dae Lee. Resources: Jong Dae Lee. Supervision: Jong Dae Lee. Visualization: Hyun Tag Kang, Yun Ji Lee. Writingoriginal draft: Hyun Tag Kang, Jae Yong Lee, Yun Ji Lee. Writing — review \& editing: Hyun Tag Kang, Se A Lee, Jong Dae Lee.

\section{ORCIDs}

Jong Dae Lee https://orcid.org/0000-0003-2866-9841 Hyun Tag Kang https://orcid.org/0000-0003-4549-8079

\section{REFERENCES}

1) Evans DG. Neurofibromatosis type 2 (NF2): A clinical and molecular review. Orphanet J Rare Dis 2009;4:16.

2) Asthagiri AR, Parry DM, Butman JA, Kim HJ, Tsilou ET, Zhuang Z, et al. Neurofibromatosis type 2. Lancet 2009;373(9679):1974-86.

3) Ardern-Holmes S, Fisher G, North K. Neurofibromatosis type 2. J Child Neurol 2017;32(1):9-22.

4) Halliday D, Emmanouil B, Pretorius P, MacKeith S, Painter S, Tomkins H, et al. Genetic Severity Score predicts clinical phenotype in NF2. J Med Genet 2017;54(10):657-64.

5) Aboukais R, Baroncini M, Zairi F, Bonne NX, Schapira S, Vincent $\mathrm{C}$, et al. Prognostic value and management of spinal tumors in neurofibromatosis type 2 patients. Acta Neurochir (Wien) 2013; 155(5):771-7.

6) Baser ME, Kuramoto L, Joe H, Friedman JM, Wallace AJ, Gillespie 
JE, et al. Genotype-phenotype correlations for nervous system tumors in neurofibromatosis 2: A population-based study. Am J Hum Genet 2004;75(2):231-9.

7) Kluwe L, Mautner VF. Mosaicism in sporadic neurofibromatosis 2 patients. Hum Mol Genet 1998;7(13):2051-5.

8) Feucht M, Kluwe L, Mautner VF, Richard G. Correlation of nonsense and frameshift mutations with severity of retinal abnormalities in neurofibromatosis 2. Arch Ophthalmol 2008; 126(10):1376-80.

9) Welling DB, Guida M, Goll F, Pearl DK, Glasscock ME, Pappas DG, et al. Mutational spectrum in the neurofibromatosis type 2 gene in sporadic and familial schwannomas. Hum Genet 1996; 98(2):189-93.

10) Committee on Hearing and Equilibrium; Monsell EM, Balkany TA, Gates GA, Goldenberg RA, Meyerhoff WL, et al. Committee on Hearing and Equilibrium guidelines for the evaluation of hearing preservation in acoustic neuroma (vestibular schwannoma). Otolaryngol Head Neck Surg 1995;113(3):179-80.

11) Emmanouil B, Houston R, May A, Ramsden JD, Hanemann CO, Halliday D, et al. Progression of hearing loss in neurofibromatosis type 2 according to genetic severity. Laryngoscope 2019;129(4): 974-80. 